\title{
Genome
}

\section{Molecular characterization and functional analysis of Iysosomal cathepsin D-like gene in red swamp crayfish, Procambarus clarkii}

\begin{tabular}{|c|c|}
\hline Journal: & Genome \\
\hline Manuscript ID & gen-2020-0154.R2 \\
\hline Manuscript Type: & Article \\
\hline $\begin{array}{r}\text { Date Submitted by the } \\
\text { Author: }\end{array}$ & 26-Apr-2021 \\
\hline Complete List of Authors: & $\begin{array}{l}\text { Huang, Long; Anhui Academy of Agricultural Sciences } \\
\text { Wu, Ben-li; Anhui Academy of Agricultural Sciences } \\
\text { He, Ji-Xiang; Anhui Academy of Agricultural Sciences } \\
\text { Zhang, Ye; Anhui Academy of Agricultural Sciences } \\
\text { Chen, Jing; Anhui Academy of Agricultural Sciences } \\
\text { Chen, Xia-jun; Anhui Academy of Agricultural Sciences }\end{array}$ \\
\hline Keyword: & cathepsins, crayfish, immune genes, immune system, microbial infection \\
\hline $\begin{array}{r}\text { Is the invited manuscript for } \\
\text { consideration in a Special } \\
\text { Issue? : }\end{array}$ & Not applicable (regular submission) \\
\hline
\end{tabular}

\section{SCHOLARONE" \\ Manuscripts}



red swamp crayfish, Procambarus clarkii

$11 *$ Corresponding author: Ji-Xiang He

12 Tel/fax: +8655165160709

13 E-mail: friaaas@163.com (JX He)

14 Address: Anhui Province Key Laboratory of Aquaculture \& Stock Enhancement, Fisher Institute 15 of Anhui Academy of Agricultural Sciences, Hefei 230031, P.R. China.

\# These authors contributed equally to this work. 


\section{Abstract}

The aspartic proteinases are one of the four families of proteinase enzymes, which are widely present among living organisms. They are involved in different physiological events such as protein degradation, development, and host defense. However, the characterization and functional roles of aspartic proteinases remain to be elucidated in crustaceans. Here, we characterized a fragment of cathepsin D-like cDNA from red swamp crayfish, Procambarus clarkii (Pc-cathepsin D-like). The Pc-cathepsin D-like gene's open reading frame contained 1152-bp, encoding a protein of 383 amino acid residues. We also evaluated the immunological role of the Pc-cathepsin D-like gene in vivo. Spatial distribution analysis revealed that the $P c$ cathepsin D-like mRNA was high in the hepatopancreas, followed by gut, gill, and hemocytes of P. clarkii. The expression levels of Pc-cathepsin D-like gene increased following challenge with viral (Polyinosinic: polycytidylic acid) and bacterial (lipopolysaccharides, peptidoglycan) PAMPs compared with PBS injection. The suppression of the Pc-cathepsin D-like gene by RNA interference significantly increased the expression of immune-associated genes. These results showed that the Pc-cathepsin D-like gene has an essential biological role in the innate immune responses since it regulates the expression of immune-associated genes.

Keywords: cathepsins; crayfish; immune genes; immune system; microbial infection 


\section{Introduction}

A lysosome is generally a house of various cathepsin molecules, divided into three categories: cysteine proteases, serine proteases, and aspartate proteases (Turk et al., 2002; Sirikharina et al., 2010). Aspartic peptidases (cathepsin D and E) catalyze molecular reactions at acidic $\mathrm{pH}$ and are sensitive towards inhibition by Pepstatin A. Their active site is characterized by the well-conserved triad Asp-Thr-Gly around the two aspartic residues located between two lobes (Fusek and Vetvicka, 2005; Söderhäll et al., 2010). Aspartic peptidases have been described in a wide range of taxa and have extensively been studied in mammals, parasites, and insects (Söderhäll et al., 2005; Valle et al., 2017; Rebello et al., 2018).

Cathepsin D, aspartic proteinase, is an essential component of the lysosome, present in almost all mammalian cells and tissues. It is produced in the rough endoplasmic reticulum as a zymogen and transported to lysosomes, where it is transformed into a mature enzyme after proteolytic cleavage (Richo and conner, 1994; Cerenius and Söderhäll, 2018; Korkut et al., 2018). Due to the capability of degrading structural and functional proteins, cathepsin D modulates a wide range of physiological functions. In parasites, cathepsin D contributes to degradation of hemoglobin (Sojka et al., 2012; Mancilla-Ole et al., 2018), muscle (Ladrat et al., 2003; Godiksen et al., 2009), and serum proteins in the host. Also, it plays a crucial role in different developmental stages in some parasites (Leyria et al., 2015). In humans, cathepsin D participates in various processes such as the pathogenesis of human neurodegenerative disorders (Zhang et al., 2010; Vidoni et al., 2016), the activation of growth factors, hormones (Jiravanichpaisal et al., 2009; Dubey et al., 2017), signaling pathways leading to cell death (Salvesen et al., 2001). Although cathepsin D has been studied intensively in the development of 
64

65

66

cancer drugs in recent years, its role in the generation of antigenic peptides and MHC class-IImediated antigen presentation has produced inconsistent results too small in different species (Tsukuba et al., 2000).

In contrast to mammals, the literature on aspartic peptidases is scanty in crustaceans (Meng et al., 2019; Liu et al., 2020). So far, only a few studies reported the physiological functions of aspartic peptidases in crustaceans. For example, a cathepsin D-like protein extracted from the American lobster's digestive tract (Homarus americanus) has been characterized for its physiological functions (Rojo et al., 2013; Rodriguez-Siordia et al., 2018). Therefore, it is much required to identify and characterize aspartic peptidases to improve our understanding of crustaceans' cathepsins. In this study, to the best of our knowledge, we first time identified the cathepsin D-like gene from red swamp crayfish, P. clarkii (Pc-cathepsin D-like), and determined its spatial and temporal distribution. We also analyzed the immunoregulatory role of the $P c$ cathepsin D-like gene after knocked it down.

\section{Materials and methods}

\subsection{Animals and sample collection}

Red swamp crayfish, $P$. clarkii (average body weight: $10 \pm 0.5 \mathrm{~g}$ ) were obtained from an aquaculture farm, Zhejiang, China. They were transported to Wenzhou Medical University and maintained in tanks with running aerated water at ambient temperature $\left(28 \pm 2{ }^{\circ} \mathrm{C}\right)$ with salinity at 15 ppt. To acclimatize, they were kept in these tanks for at least two weeks, and the animals were fed with natural (insect larvae and water snail) and commercial diet (Chu et al., 2019; Abbas et al., 2019; Li et al., 2020). For the spatial analysis of Pc-cathepsin D-like gene, muscle, 
heart, stomach, hepatopancreas, gut, hemocyte, and gill were sampled and stored at $-80{ }^{\circ} \mathrm{C}$ until further use. Three experimental groups (injected with $1 \mathrm{mg} / \mathrm{mL}$ PGN (bacterial peptidoglycan) or $1 \mathrm{mg} / \mathrm{mL}$ LPS (bacterial lipopolysaccharide) or $1 \mathrm{mg} / \mathrm{mL}$ poly $\mathrm{I}: \mathrm{C}$ ) and the control group (injected with $1 \mathrm{mg} / \mathrm{mL}$ PBS) were established to investigate the response of Pc-cathepsin Dlike after stimulation under biotic stress, with 20 individuals in each group. Hepatopancreas tissue from individuals at time points of $3,6,12,24,36$, and $48 \mathrm{~h}$ after treatment were collected for Pc-cathepsin D-like mRNA level detection, separately. Three additional groups were used for the RNA interference test, with 20 individuals in each group.

\subsection{Full-length cDNA cloning of the Pc-cathepsin D-like gene}

For the full-length Pc-cathepsin D-like cDNA cloning, the total RNA was extracted from the hepatopancreas of $P$. clarkii using the Trizol reagent (Invitrogen, Carlsbad, CA, USA) and then purified using a QuickPrep Micro mRNA Purification Kit (GE Healthcare, USA). The firststrand cDNA was prepared using the TransScript Synthesis SuperMix (TransGen, Beijing, China) according to the manufacturer's instructions. The nucleotide sequence of the $P c$ cathepsin D-like gene was obtained from the P. clarkii genome library, which was previously constructed in our laboratory (Dai et al., 2017; Zhou et al., 2017). For cloning the Pc-cathepsin D-like gene, gene-specific primers were designed using partial sequences in the $P$. clarkii database mentioned above using Oligo 7.0 software (Table 1). Thermal cycling for polymerase chain reaction (PCR) was as followed: $94{ }^{\circ} \mathrm{C}$ for $3 \mathrm{~min}, 35$ cycles at $94{ }^{\circ} \mathrm{C}$ for $30 \mathrm{~s}, 55^{\circ} \mathrm{C}$ for 35 $\mathrm{s}$ and $72{ }^{\circ} \mathrm{C}$ for $45 \mathrm{~s}$. The PCR products were subjected to agarose gel (1\%) electrophoresis, and the gene of interest was purified for further analysis. The purified fragment was then inserted into the pMD19-T Vector and sequenced by Invitrogen. 


\subsection{Bioinformatics analysis}

108

109

110

111

112

113

For homology analysis, the cathepsin D-like cDNA was analyzed by the BLAST program (http:// www.ncbi.nlm.nih.gov/blast). The deduced amino acid sequence of cathepsin D-like was obtained from the Expert Protein Analysis System (http://www.expasy.org/). Multiple sequence alignments were performed in Clustal X software (Thompson et al., 1997). A phylogenetic tree was constructed with cathepsin D from different animal species using MEGA 6 software (1000 bootstrap replicates) by the Neighbor-Joining (NJ) method (Tamura et al., 2011).

\subsection{Determination of the tissue localization of cathepsin D-like mRNA}

A quantitative real-time PCR (qPCR) assay was used for mRNA expression level detection. The total RNAs of sampled tissues were reverse transcribed into cDNA using a TransScript Synthesis SuperMix (TransGen, Beijing, China). Oligonucleotide primers specific for the cathepsin D-like sequence were designed by using Primer 5.0 software (Table 1). The PCR was performed at a total volume of $25 \mu \mathrm{L}$ containing $12.5 \mu \mathrm{L} 2 \times$ SYBR Premix Ex TaqII (Takara), $2 \mu \mathrm{L}$ of diluted cDNA template, $2 \mu \mathrm{L}$ primer mix, and $8.5 \mu \mathrm{L}$ RNase-free $\mathrm{H}_{2} \mathrm{O}$. The PCR programs were set as follows: initial denaturation at $95{ }^{\circ} \mathrm{C}$ for $3 \mathrm{~min}$, followed by 40 cycles at $95{ }^{\circ} \mathrm{C}$ for $10 \mathrm{~s}, 55^{\circ} \mathrm{C}$ for $30 \mathrm{~s}$, and $72{ }^{\circ} \mathrm{C}$ for $30 \mathrm{~s}$. The continuous fluorescence acquisition 65 $95{ }^{\circ} \mathrm{C}$ with an increase of $0.5^{\circ} \mathrm{C}$ per $10 \mathrm{~s}$ was used for melting curve analysis. The relative expression of the cathepsin D-like gene was calculated according to the $2^{-\Delta \Delta \mathrm{CT}}$ method (Livak, and Schmittg, 2001), and the 18S rRNA gene was used as an endogenous control.

\subsection{Expression profiles of cathepsin D-like gene under biotic stress}


Three of the four groups of red swamp crayfish were injected with PGN, LPS, or poly

128

129

130

131

132

133

134

135

136

I:C, $1 \mathrm{mg} / \mathrm{mL}$, respectively. The rest of the group treated with only PBS was used as the control. These injections were delivered with a Hamilton Microliter ${ }^{\mathrm{TM}}$ syringe (Sigma-Aldrich, China). Four organisms were taken as one sample, and the biological sampling protocol was repeated three times. At 3, 6, 12, 24, 36, and $48 \mathrm{~h}$ post-injection, hepatopancreas from twenty individual crayfish were collected into liquid nitrogen and stored at $-80^{\circ} \mathrm{C}$ until RNA isolation. The mRNA distribution of cathepsin D-like gene was analyzed by qRT-PCR using the same protocol as described in section 2.4.

\subsection{Effect of cathepsin D-like silencing on the expression of immune-pathways associated} genes

To investigate the effect of cathepsin D-like gene depletion on the expression of genes related to the immune pathway, double-stranded (ds) RNAs of cathepsin D-like gene and fluorescent protein (EGFP) were prepared by following the protocol of T7 RiboMAX Express RNAi System (Promega, USA). A template for in vitro transcription reactions was prepared by PCR amplification of a clone containing the cathepsin D-like gene ORF using gene-specific primers (Table 1) with a T7 polymerase binding sequence at 5' end, as described before in section 2.4, except for a change in the cDNA templates. After phenol-chloroform extraction and heat treatment, the dsRNA was diluted with nuclease-free water to a final concentration of $10 \mu \mathrm{L}$ $(1 \mu \mathrm{g} / \mu \mathrm{L})$ for injection into red swamp crayfish. EGFP dsRNA and nuclease-free DEPC water were served as negative controls injected with the same dose. Twenty red swamp crayfish were treated in each independent experiment, respectively. The needles were kept still at the injection point for the $30 \mathrm{~s}$. Hemocyte samples were collected from each treatment group at 24 and $48 \mathrm{~h}$ 
149 after injection. Total RNA was isolated and used for the expression analysis of immune-pathway 150 associated genes.

151

152

153

154

155

156

157

158

159

160

161

162

163

164

165

166

167

168

\subsection{Data analysis}

Statistical analysis was one-way analysis variance (ANOVA) followed by Tukey's test and performed using SPSS version 17.0. The difference with a $p$-value less than 0.05 were considered statistically for all treatments.

\section{Results}

\subsection{Bioinformatics analysis of Pc-cathepsin D-like}

The full-length cDNA sequence of Pc-cathepsin D-like comprised a 1152 bp open reading frame $(\mathrm{ORF})$. The $\mathrm{ORF}$ sequence encoded a protein of 383 amino acid residues with a calculated molecular weight of $41.47 \mathrm{KDa}$ and an isoelectric point of almost 4.35. The protein had a signal peptide of 16 amino acid residues and two active sites (D) motif at amino acid residues 81 and 268, respectively (Fig. 1). The deduced amino acid sequence of cathepsin D-like shared the highest identity (73.59 aa) to that of $P$. vannamei followed by H. americanus (74.09 aa), while lowest identity (47.37 aa) to that of $H$. sapiens. Five conserved cysteine residues dispersed throughout the Pc-cathepsin D-like sequence (shown as dots), and two active sites motif at amino acid residues 81 and 268 (shown as arrows) (Fig. 2).

To understand the evolutionary relationship of Pc-cathepsin D-like protein with cathepsin D or D-like proteins from other animal species, a phylogenetic tree was constructed using amino acid sequences of selected invertebrate and vertebrate species (Fig. 3). The results revealed that 
169 crustaceans cathepsin D were clustered into one clade, which was separated obviously from the

170 clade of mollusk, insects, mammals, and fishes. In the crustacean's clade, Pc-cathepsin D-like

171 exhibited a close relationship with Penaeus vannamei, Homarus americanus, Homarus

172 Gammarus, which is in line with the results of sequence (amino acid) identity analysis.

\subsection{Expression profiles of cathepsin D-like gene in different tissues}

To determine the expression profile of the Pc-cathepsin D-like gene in various tissues

\subsection{Expression profiles of Pc-cathepsin D-like genes under biotic stress}

The temporal expression of the Pc-cathepsin D-like was determined in the hepatopancreas using the qRT-PCR assay. A significant change in Pc-cathepsin D-like expression was found in hepatopancreas after the poly I:C, LPS, and PGN treatment. However, both the mRNA level and the time of the highest mRNA expression were not synchronized among them. In the hepatopancreas, red crayfish challenged by poly I:C exhibited approximately equal transcript level to the control group after infection for $3 \mathrm{~h}$ (Fig. 5A). However, the level of expression reached its peak after $24 \mathrm{~h}$ of treatment. The maximum expression of the Pc-cathepsin D-like gene was observed after $6 \mathrm{~h}$ of LPS treatment (Fig. 5B), and this occurred after 6 and $36 \mathrm{~h}$ of PGN treatment (Fig. 5C). 


\subsection{Pc-cathepsin D-like regulates the expression of genes associated with immune-} pathways

To determine the possible role of Pc-cathepsin D-like gene in innate immune responses, the transcript patterns of different genes related to the immune pathways were quantified following the depletion of Pc-cathepsin D-like by dsRNA, and the dsEGFP treated individuals were used as control. The efficiency of dsRNA administration at $24 \mathrm{~h}$ and $48 \mathrm{~h}$ was analyzed by executing qRT-PCR (Fig. 6A). The expression of all the tested immune-pathway associated genes (Serine/threonine protein kinase, Anti-lipopolysaccharide factor, Sptäzle, Cactus, Lectinlike, and Toll3) was significantly increased in the Pc-cathepsin D-like silenced group compared with the dsEGFP control (Fig. 6B). These results suggest that Pc-cathepsin D-like has a crucial biological role in the immune responses of $P$. clarkii since it can modulate genes associated with immune pathways. To further ensure our results, we analyzed the expression levels of nonimmunity genes, including oxysterol binding protein 1 and Ecdysteroid receptor. The results revealed that the depletion of Pc-cathepsin D-like did not affect the expression of non-immunity genes.

\section{Discussion}

In this study, we identified and characterized a cathepsin D-like cDNA from red swamp crayfish, $P$. clarkii. Pc-cathepsin D-like cDNA encoded a predicted protein of 383 amino acids, including the peptidase domain containing the active sites that are the characteristic feature of cathepsin D-like proteins. Amino acid sequence analyses revealed Pc-cathepsin D-like showed $47.37 \%-74.09 \%$ identity to cathepsin proteins from other species, including crustaceans and vertebrates. Phylogenetic analysis exhibited that Pc-cathepsin D-like was most closely related to 
211 P. vannamei cathepsin D. In living organisms, cathepsin D participates in different molecular 212 reactions to maintain homeostasis. In parasites, cathepsin D controls the degradation of serum 213 proteins, haemoglobin, and muscle in the host (Godiksen et al., 2009; Sojka et al., 2012; 214 Mancilla-Olea et al., 2018). Moreover, it regulates various physiological processes, including 215 immune responses, cell death-related signaling pathways, etc., in invertebrates and vertebrates 216 (Dubey et al., 2017; Vidoni et al., 2016; Sun et al., 2017). Thus, it is much needed to explore the 217 biological role of cathepsin D to understand physiological functions and molecular mechanisms 218 in economically important animals, including crustaceans. and found it to be very similar to those of cathepsins of other crustaceans (Apitanyasai et al., 221 2016; Sun et al., 2018; Liu et al., 2020; Huang et al., 2020). In healthy and non-induced $P$. 222 clarkii, Pc-cathepsin D-like mRNA was expressed in all the tested tissues, including muscle, 223 heart, stomach, hepatopancreas, gut, hemocyte, and gill. However, the expression was remarkably higher in hepatopancreas and gut, and the expression was lowest in muscle. The 225 hepatopancreas is implicated in the immune response by producing immune factors such as 226 lectins, nitric oxide, hemocyanin and antimicrobial peptides to prevent microbial diseases. 227 Additionally, it modulates secretion of digestive enzymes, digestion of carbohydrates and fat, 228 absorption of nutrients, and storage of energy in the form of lipid etc., suggesting the 229 multifunctional organ in crustaceans (Yasothornsrikul et al., 2003; Benes et al., 2008; Chen et 230 al., 2011; Liu et al., 2019). Thus, the high level of Pc-cathepsin D-like mRNA in the 231 hepatopancreas suggests that Pc-cathepsin D-like may play a similar role in $P$. clarkii like other 232 cathepsins. 
Many authors reported the upregulation of cathepsins in tissues/organ of aquatic

234 invertebrates infected with microbial pathogens. For example, cathepsin $\mathrm{A}$ and $\mathrm{C}$ gene

235

236

237

238

239

240

241

242 expression were upregulated in the hepatopancreas of crayfish infected with bacterial and viral pathogens (Oidtmann et al., 2004; Liu et al., 2020; Huang et al., 2020). In both cases, the crayfish exposed to pathogens for different time periods to evaluate the change in the expression of cathepsins. Infection of Spiroplasma eriocheiris in Eriocheir sinensis has also been reported to increase the expression of cathepsin D gene (Ning et al., 2018). In this case, the crustacean was exposed to the pathogen for a long period (for nine days). In the present study, $P$. clarkii was infected with immune elicitors (virus and bacteria) for a short period (time points: $3,6,12,24$, 36, and $48 \mathrm{~h}$ ). The expression of the Pc-cathepsin D-like gene in the hepatopancreas was strongly increased at critical time points of infection. Pc-cathepsin D-like expression profiles are consistent with the previous studies, although the time exposed to the microbial pathogen is different. A recent study suggested that recognition and regulator genes are usually enhanced after microbial infection (Xiong et al., 2015; Abbas et al., 2020a; Abbas et al., 2020b). Thus, we proposed that $P c$-cathepsin D-like might implicate in the regulation of immune genes in the $P$. clarkii.

Immune-pathway associated genes are important molecules that indicate the immunepathways activity, and their mRNA expression can be either ubiquitous in a basal level or stimulated following pathogen challenge (Min et al., 2017; Sun et al., 2017; Abbas et al., 2017). The IMD and Toll signaling pathways and their related molecules are the primary components of the innate immune system, which regulate immune effectors, e.g., the production of antimicrobial proteins (Min et al., 2017; Kausar et al., 2017, 2018). After the microbial invasion, Toll receptors detect microbial pathogens' components, thereby transfer signals to the 
256 downstream molecules (Uematsu and Akira, 2006; Medzhitov et al., 2007; Kausar et al., 2019).

257 Several studies reported the enhancement of expression of Toll receptors after challenge with 258 LPS and Vibrio anguillarum in F. chinensis, M. japonicus, and L. vannamei (Xu et al., 2000; 259 Yang et al., 2008; Dai et al., 2018). The stimulation of Toll receptors is associated with activation of immune pathways, subsequently, induce the expression of immune effectors such as 261 ALF to inhibit infection (Ma et al., 2019; Zhu et al., 2019). However, the modulation of the expression of Toll receptors and other immune genes is less explored in crustaceans. In the present study, we found that Pc-cathepsin D-like silencing resulted in an upregulation of all the tested genes, including Serine/threonine protein kinase, Lectin-like, Sptäzle, Antilipopolysacchride, Toll3, and Cactus in the hepatopancreas of $P$. clarkii. The upregulated genes mainly contribute to immune functions in the crustacean. Toll receptors recognize of microbial pathogens and activate immune responses. Sptzale is an extracellular ligand that induces innate immunity via binding with Toll receptor after detecting pathogens, and cactus has antifungal functions, and so on. In addition, the expression levels of Toll3 and lectin-like were higher after $48 \mathrm{~h}$ of Pc-cathepsin D-like silencing; even the down-regulation of the gene was

271 almost similar at both the time points, suggesting both the genes may follow time-dependent expression patterns or different animals may have a different response in similar conditions. Additionally, non-immunity genes expression remains unchanged in Pc-cathepsin D-like and control. Altogether, these results allowed us to infer that Pc-cathepsin D-like is involved in the regulation of immune-pathway associated genes. The involvement of cathepsins in the modulation of immune genes is not entirely a new phenomenon, and it has also been reported in many other studies (Liu et al., 2020; Huang et al., 2020). However, further research is required to elucidate molecular mechanisms by which cathepsins regulate immune genes. 
In summary, the full-length cDNA sequence of Pc-cathepsin D-like from red swamp crayfish, P. clarkii was cloned and molecularly characterized. The Pc-cathepsin $D$-like is produced in all tested tissue, and challenge with immune elicitors induced its expression. We also observed that Pc-cathepsin D-like contributes to the regulation of immune-pathway associated genes.

\section{Acknowledgements}

This work was supported by the National Key Research and Development Project of China (2018YFD0300904), the central government Guiding Local Science and Technology Development for Anhui Province (201907d06020015), the Scientific and Technological Innovation Team of Anhui Academy of Agricultural Sciences (2020YL041).

\section{Competing interests}

The authors have declared that no competing interests exist.

\section{References}

Abbas, M.N. Kausar, S., Zhao, E., Cui, H. 2020a. Suppressors of cytokine signaling proteins as modulators of development and innate immunity of insects. Dev. Comp. Immunol. 104, 103561.

Abbas, M.N., Kausar, S. Sun, Y.X., Sun, Y., Wang, L., Qian, C., Wei, G.Q., Zhu, B.J., Liu, C.L. 2017. Molecular cloning, expression, and characterization of E2F transcription factor 4 from Antheraea pernyi. Bull. Entomol. Res. 1, 8.

Abbas, M.N., Kausar, S., Cui, H., 2019. The biological functions of peroxiredoxins in innate immune responses of aquatic invertebrates. Fish Shellfish Immunol. 89, 91-97.

Abbas, M.N., Liang, H., Kausar, S., Dong, Z., Cui, H. 2020b. Zinc finger protein RP-8, the Bombyx mori ortholog of programmed cell death 2, regulates cell proliferation. Dev. Comp. Immunol. 104, 103542. 
Apitanyasai, K., Noonin, C., Tassanakajon, A., Söderhäll, I., Söderhäll, K., 2016. Characterization of a hemocyte homeostasis-associated-like protein (HHAP) in the freshwater crayfish Pacifastacus leniusculus. Fish Shellfish Immunol. 58, 429-435.

Benes, P., Vetvicka, V., Fusek, M., 2008. Cathepsin D: many functions of one aspartic protease. Crit. Rev. Oncol. Hematol. 68, 12-28.

Cerenius, L., Söderhäll, K., 2018. Crayfish immunity: Recent findings. Dev. Comp. Immunol. 80, 94-98.

Chen, L., Zhang, M. Sun, L., 2011. Identification and expressional analysis of two cathepsins from half-smooth tongue sole (Cynoglossus semilaevis). Fish Shellfish Immunol. 31, 12701277.

Chu, S.H., Liu, L., Abbas, M.N., Li, Y.Y., Kausar, S. Qian, X.Y., Ye, Z.Z., Yu, X.M., Li, X.K., Liu, M., Dai, L.S., 2019. Peroxiredoxin 6 modulates Toll signaling pathway and protects DNA damage against oxidative stress in red swamp crayfish (Procambarus clarkii). Fish Shellfish Immunol. 89, 170-178.

Dai, L.S., Abbas, M.N., Kausar, S., Zhou, Y., 2017. Transcriptome analysis of hepatopancraes of Procambarus clarkii challenged with polyriboinosinic polyribocytidylic acid (poly I:C). Fish Shellfish Immunol. 71, 144-150.

Dai, L.S., Yu, X.M., Abbas, M.N., C.S. Li, Chu, S.H., Kausar, S., Wang, T.T. 2018. Essential role of the peroxiredoxin 4 in Procambarus clarkii antioxidant defense and immune responses. Fish Shellfish Immunol. 75, 216-222.

Dubey, V., Luqman, S., 2017. Cathepsin D as a promising target for the discovery of novel anticancer agents. Curr. Cancer Drug Targets. 17, 404-422.

Fusek, M., Větvička V., 2005. Dual role of cathepsin D: ligand and protease. Biomed. Papers. $149,43-50$.

Godiksen, H., Morzel, M., Hyldig, G., Jessen, F., 2009. Contribution of cathepsins B, L and D to muscle protein profiles correlated with texture in rainbow trout (Oncorhynchus mykiss). Food Chem. 113, 889-896.

Huang, L., Dai, L.S., Wu, B.L., Zhang, Y., Chen, J., He, J.X., 2020. Identification and immunoregulatory role of cathepsin A in the red swamp crayfish, Procambarus clarkii. Int. J. Biol. Macromol. 153, 865-872. 
Jiravanichpaisal, P., Roos, S., Edsman, L., Liu, H., Söderhäll, K., 2009. A highly virulent pathogen, Aeromonas hydrophila, from the freshwater crayfish Pacifastacus leniusculus. J. Invert. Pathol. 101, 56-66.

Kausar, S. Abbas, M.N., Zhao, Y., Cui, H. 2019. Immune strategies of silkworm, Bombyx mori against microbial infections. Invert. Surviv. J. 16, 130-140.

Kausar, S., Abbas, M.N., Qian, C. Zhu, B.J., Gao, J., Sun, Y., Wang, L., Wei, G.Q., Liu, C.L. 2018. Role of Antheraea pernyi serpin 12 in prophenoloxidase activation and immune responses. Arch. Insect Biochem. Physiol. e21435.

Kausar, S., Qian, C., Abbas, M.N., Zhu, B.J., Liu, Y., Wang, L., Wei, G.Q., Sun, Y., Liu, C.L. 2017. Characterization and functional analysis of serpin-10 gene from oak silkworm Antheraea pernyi. Eur. J. Entomol. 114, 430-438.

Korkut, G.G., Söderhäll, I., Söderhäll, K., Noonin, C., 2018. The effect of temperature on bacteria-host interactions in the freshwater crayfish, Pacifastacus leniusculus. J. Invert. Pathol. 157, 67-73.

Ladrat, V., Verrez-Bagnis, Noel, J., Fleurence, J., 2003. In vitro proteolysis of myofibrillar and sarcoplasmic proteins of white muscle of sea bass (Dicentrarchus labrax L.): effects of cathepsins B, D and L. Food Chem. 81, 517-525.

Leyria, J., Fruttero, L.L., Nazar, M., Canavoso, L.E., 2015. The Role of DmCatD, a cathepsin Dlike peptidase, and acid phosphatase in the process of follicular atresia in Dipetalogaster maxima (Hemiptera: Reduviidae), a vector of chagas' disease. PLoS One. 10, e0130144.

Li, C.S., Kausar, S., Gul, I., Yao, X.X., Li, M.Y., Chen, C.C., Abbas, M.N., Dai, L.S., 2020. Heat shock protein 20 from Procambarus clarkii is involved in the innate immune responses against microbial infection. Dev. Comp. Immunol. 106, 103638.

Liu, M., Liu L., Abbas, M.N., Kausar, S., Zhang, J.W., Ye, Z.Z., Qian, X.Y., Zhao, X.M., Chu, S.H., Dai, L.S., 2019. Involvement of gamma interferon inducible lysosomal thiol reductase in the innate immune responses of red swamp crayfish, Procambarus clarkii. Dev. Comp. Immunol. 99, 103405.

Liu, Q.N., Kausar, S., Gul, I., Zhou, H.L., Abbas, M.N., Dai, L.S., 2020. The red swamp crayfish, Procambarus clarkii cathepsin C, participates in the innate immune response to the viral and bacterial pathogens. Fish shellfish Immunol. 100, 436-444 
Livak, K.J., Schmittgen, T.D., 2001. Analysis of relative gene expression data using real-time quantitative PCR and the 2(-Delta Delta C(T)) method. Methods. 25, 402-408.

Ma, H., Abbas, M.N., Zhang, K., Hu, X., Xua, M., Liang, H., Kausar, S., Yang, L., Cui, H. 2019. 20-Hydroxyecdysone regulates the transcription of the lysozyme via Broad Complex Z2 gene in silkworm, Bombyx mori. Dev. Comp. Immunol. 94, 66-72.

Mancilla-Olea, M.I., Ortega-López, J., Figueroa-Angulo, E.E., Avila-González, L., CárdenasGuerra, R.E., Miranda-Ozuna, J.F.T., González-Robles, A., Hernández-García, M.S., Sánchez-Ayala, L. Arroyo, R., 2018. Trichomonas vaginalis cathepsin D like aspartic proteinase (Tv-CatD) is positively regulated by glucose and degrades human hemoglobin. Int. J. Biochem. Cell Biol. 97, 1-15.

Medzhitov, R. 2007. TLR-mediated innate immune recognition. Semin. Immunol. 19, 1-2.

Meng, X., Hong, L., Yang, T.T., Liu, Y., Jiao, T., Chu, X.H., Zhang, D.Z., Wang, J.L., Tang, B.P., Liu, Q.N., Zhang, W.W., He, W.F., 2019. Transcriptome-wide identification of differentially expressed genes in Procambarus clarkii in response to chromium challenge. Fish Shellfish Immunol. 87, 43-50.

Min, Y.H., Zhu, B.J., Sun, Y., Wei, G.Q., Wang, L., Qian, C., Abbas, M.N., Liu, C.L. 2017. Characterization and functional analysis of serpin-1 like gene from oak silkworm Antheraea pernyi. Bull. Entomol. Res. 1, 7.

Ning, M., Yuan, M., Liu, M., Gao, Q., Wei, P., Gu, W., Wang, W., Meng, Q., 2018. Characterization of cathepsin D from Eriocheir sinensis involved in Spiroplasma eriocheiris infection. Dev. Comp. Immunol. 86, 1-8.

Oidtmann, B., Schaefers, N., Cerenius, L., Söderhäll, K., Hoffmann. R.W., 2004. Detection of genomic DNA of the crayfish plague fungus Aphanomyces astaci (Oomycete) in clinical samples by PCR. Vet. Microbiol. 100, 269-282.

Rebello, K.M., McKerrow, J.H., Mota, E.M., Donoghue, A.J. O., Neves-Ferreira, A.G.C., 2018. Activity profiling of peptidases in Angiostrongylus costaricensis first-stage larvae and adult worms. PLoS Negl. Trop. Dis. 31, e0006923.

Richo, G.R., Conner, G.E., 1994. Structural requirements of procathepsin D activation and maturation. J. Biol. Chem. 269 ,14806-14812. 
Rodriguez-Siordia, I., Rojo-Arreola, L., Navarrete Del Toro, M.L.A., García-Carreño, F., 2018. American lobster cathepsin D, an aspartic peptidase resistant to proteolysis and active in organic solvents, non-ionic detergents and salts. Int. J. Biol. Macromol. 107, 1501-1509.

Rojo, L., García-Carreno, F., Navarrete Del Toro, M.L.A., 2003. Cold-adapted digestive aspartic protease of the clawed lobsters homarus americanus and homarus gammarus: biochemical characterization. Mar. Biotechnol. 15, 87-96.

Salvesen, G.S., 2001. A lysosomal protease enters the death scene. J. Clin. Invest. 107, 21-22.

Shi, H., Ruan, L., Söderhäll, I., Soderhall, K., Xu, X., 2018. Transfection of crayfish hematopoitic tissue cells. Dev. Comp. Immunol. 88, 70-76.

Sirikharina, R., Söderhäll, I., Söderhäll, K., 2018. Characterization of a cold-active transglutaminase from a crayfish, Pacifastacus leniusculus. Fish Shellfish Immunol. 80, 546-549.

Söderhäll, I., Kim, Y.A., Jiravanichpaisal, P., Lee, S.Y., Söderhäll, K., 2005. An ancient role for a prokineticin domain in invertebrate hematopoiesis. J. Immunol. 174, 6153-6160.

Söderhäll, K., 2010. Invertebrate immunity. Preface. Adv. Exp. Med. Biol. 708, vii-ix.

Sun, Y.X., Zhu, B.J., Tang, L., Sun, Y., Chen, C., Abbas, M.N., Wang, L., Qian, C., Wei, G.Q., Liu, C.L., 2017. Cathepsin O is Involved in the Innate Immune Response and Metamorphosis of Antheraea pernyi. J. Invertebr. Pathol. 150, 6-14.

Sun, Y.X., Zhu, B.J., Tang, L., Sun, Y., Chen, C., Abbas, M.N., Wang, L., Qian, C., Wei, G.Q., Liu, C.L. 2017. Cathepsin O is involved in the innate immune response and metamorphosis of Antheraea pernyi. J. Invertebr. Pathol. 150, 6-14.

Sun, Y.X., Tang, L., Wang, P., Abbas, M.N., Tian, J.W., Zhu, B.J., Liu, C.L., 2018. Cathepsin Llike protease can regulate the process of metamorphosis and fat body dissociation in Antheraea pernyi. Dev. Comp. Immunol. 78, 114-123.

Tamura, K., Peterson, D., Peterson, N., Stecher, G., Nei, M., Kumar, S., 2011. MEGA5: molecular evolutionary genetics analysis using maximum likelihood, evolutionary distance, and maximum parsimony methods. Mol. Biol. Evol. 28, 2731-2739.

Turk, V., Turk, B., Guncar, G., Turk, D., 2002. Lysosomal cathepsins: structure, role in antigen processing and presentation, and cancer. Adv. enzyme Regul. 42, 285-304.

Uematsu, S., Akira, S. 2006. Toll-like receptors and innate immunity. J. Mol. Med. 84, 712-725. 
Valle, R.S., Ramos, L.S., Reis, V.J., Ziccardi, M., Dornelas-Ribeiro, M., Sodré, C.L., Branquinha, M.H., Santos, A.L.S., 2017. Trichosporon asahii secretes a 30-kDa aspartic peptidase. Microbiol. Res. 205, 66-72.

Vidoni, C., Follo, C., Savino, M., Melone, M.A., Isidoro, C., 2016. The role of cathepsin D in the pathogenesis of human neurodegenerative disorders. Med. Res. Rev. 36, 845-870.

Xiong, G.H., Xing, L.S., Lin, Z., Saha, T.T., Wang, C., Jiang, H., Zou, Z., 2015. High throughput profiling of the cotton bollworm Helicoverpa armigera immuno-transcriptome during the fungal and bacterial infections. BMC Genomics. 16, 321.

Xu, Y., Tao, X., Shen, B., Horng, T., Medzhitov, R., Manley, J.L., Tong, L. 2000. Structural basis for signal transduction by the Toll/interleukin-1 receptor domains. Nature. 408, 111115.

Yang, C., Zhang, J., Li, F., Ma, H., Zhang, Q., Jose Priya, T.A., Zhang, X., Xiang, J. 2008. A Toll receptor from Chinese shrimp Fenneropenaeus chinensis is responsive to Vibrio anguillarum infection. Fish Shellfish Immunol. 24, 564-574.

Yasothornsrikul, S., eenbaum, D., Medzihradszky, K.F., Toneff, T., Bundey, R., Miller, R., 2003. Cathepsin L in secretory vesicles functions as a prohormone-processing enzyme for production of the enkephalin peptide neurotransmitter. Proc. Natl. Acad. Sci. USA. 100, 9590-9595.

Zhang, Y., Söderhäll, I., Söderhäll, K., Jiravanichpaisal, P., 2010. Expression of immune-related genes in one phase of embryonic development of freshwater crayfish, Pacifastacus leniusculus. Fish Shellfish Immunol. 28, 649-653.

Zhou, M., Abbas, M.N., Kausar, S., Jiang, C.X., Dai, L.S., 2017. Transcriptome profiling of red swamp crayfish (Procambarus clarkii) hepatopancreas in response to lipopolysaccharide (LPS) infection. Fish Shellfish Immunol. 71, 423-433.

Zhu, J.J., Ye, Z.Z., Li, C.S., Kausar, S., Abbas, M.N., Xiang, G.H., Qian, X.Y., Dai. L.S. 2019. Identification and molecular characterization of a novel anti-lipopolysaccharide factor (ALF) from red swamp crayfish, Procambarus clarkii. Int. J. Biol. Macromol. 132, 43-50. 


\section{Figure legends}

Fig. 1 Nucleotide and deduced amino acid sequences of Pc-cathepsin D-like gene. Signal peptides (1-16 aa) are underlined, the Peptidase domain is boxed, and active sites are shaded with yellow colour. The start and stop codons were showed by box and asterisk, respectively.

Fig. 2 Multiple sequence alignment of the Pc-cathepsin D-like protein from Procambarus clarkii with other cathepsin D proteins. The deduced amino acid sequence of Pc-cathepsin Dlike was aligned with the cathepsin D proteins from P. vannamei (ROT61198.1), H. americanus (ACG70181.1), P. carinicauda (AGJ03549.1), P. monodon (ABQ10738.1), and H. sapiens (AAA51922.1). Cysteine residues and active sites are shown by dot and arrow symbol, respectively.

\section{Fig. 3. Neighbour-joining phylogenetic for the Procambarus clarkii cathepsin D-like amino} acid sequence, constructed by MEGA 6 software. The phylogenetic tree was investigated with 10,000 bootstrap replications, and the bootstrapping values were shown via numbers at the nodes. The Procambarus clarkii cathepsin D-like is marked with rhombus-shaped, and GenBank number is given in parenthesis.

Fig. 4. The expression patterns of Pc-cathepsin D-like in different tissues of Procambarus clarkii by qRT-PCR. Bars represent the mean \pm S.E. $(n=3)$.

Fig. 5. The Pc-cathepsin D-like expression profiles in the hepatopancreas of Procambarus clarkii following challenge with immune elicitors. Pc-cathepsin D-like expression patterns in the hepatopancreas of Procambarus clarkii treated with LPS (A), PGN (B), and Poly I:C (C). PBS was used as control. Bars represent mean \pm S.E. $(n=3)$. All data were analyzed by one-way 
474 analysis of variance. It was considered statistically significant when $p$-values less than 0.05 and 475 indicated by an asterisk (*).

476 Fig. 6. (A) RNA interference efficiency of Pc-cathepsin D-like in the hepatopancreas of 477 Procambarus clarkii by qRT-PCR. The relative expression of Pc-cathepsin D-like was 478 quantified at 24 and $48 \mathrm{~h}$ after the dsRNA administration. The dsEGFP treated group was used as 479 a control. All data were analyzed by t-test analysis. It was considered statistically significant 480 when $p$-values were less than 0.05 and indicated by an asterisk (*). (B) Effects of Pc-cathepsin 481 D-like silencing on the expression levels of immune-pathways associated genes. Expression 482 of immune-pathways related genes in the hepatopancreas of Procambarus clarkii following Pc483 cathepsin D-like RNA interference. All data were analyzed by $t$-test analysis. It was considered 484 statistically significant when $p$-values were less than 0.05 and indicated by an asterisk $(*)$.

485 Table 1 Primers used in this study 
Fig. 1 Nucleotide and deduced amino acid sequences of Pc-cathepsin D-like gene.

1 ACGGGGGATCAACCCGTCAACATCACCCGCCACTCTCACACCAACATGAAGTCCTTCGCC

1

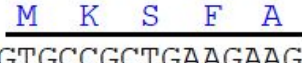

61 TGCCTCCTGCTCCTGGTGGCCCTGGTCGCTGCCGAAATCCACAGAGTGCCGCTGAAGAAG

$\begin{array}{lllllllllllllllllllll} & \mathrm{C} & \mathrm{L} & \mathrm{L} & \mathrm{L} & \mathrm{L} & \mathrm{V} & \mathrm{A} & \mathrm{L} & \mathrm{V} & \mathrm{A} & \mathrm{A} & \mathrm{E} & \mathrm{I} & \mathrm{H} & \mathrm{R} & \mathrm{V} & \mathrm{P} & \mathrm{L} & \mathrm{K} & \mathrm{K}\end{array}$

121 GTGGAGCGGAAGAGGACCCTGCAGGACCTCCGTCGCTCCCACGCCTTCCTGGCTCACCGT

$\begin{array}{llllllllllllllllllllll}26 & V & E & R & K & R & T & L & Q & D & L & R & R & S & H & A & F & L & A & H & R\end{array}$

181 TACGGCGCCAAGGACGACATCATCGTCATCGACGACTACCAAGACGCTCAGTACTATGGA

$\begin{array}{llllllllllllllllllllll}46 & Y & G & A & K & D & D & I & I & V & I & D & D & Y & Q & D & A & Q & Y & Y & G\end{array}$

241 CCСАTTAGCATCGGGACGCCCGGGCAAGGGTTTGATATCATCTTCGACACTGGATCGTCC

$\begin{array}{llllllllllllllllllllll}66 & P & I & S & I & G & T & P & G & Q & G & F & D & I & I & F & D & T & G & S & S\end{array}$

301 AACCTTTGGGTGCCGTCTGAACAGTGCAGCATCATCAACCTGGCCTGTCAGACGCACAAC

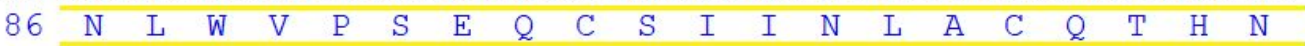

361 CGCTACGACTCCACGCTCTCCTCCTCCTACAAAGCCAACGGCACCGACTTCGCCATAGAG

$\begin{array}{lllllllllllllllllllll}106 & R & Y & D & S & T & L & S & S & S & Y & K & A & N & G & T & D & F & A & I & E\end{array}$

421 TACGGCTCTGGCTCCCTCACCGGCTTCCTTTCCAGCGACACGGTGGCAGTCGGGGACTTG

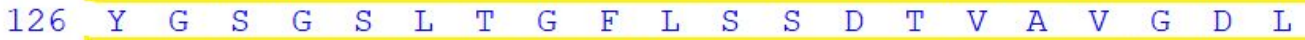

481 GCTGTCGTTGACCAGACCTTCGCTGAGGCCACCCACGAGCCTGGCATAGCCTTCCTGGCG

$\begin{array}{lllllllllllllllllllll}146 & A & V & V & D & Q & T & F & A & E & A & T & H & E & P & G & I & A & F & \text { L } & \text { A }\end{array}$

541 GGCGTGTTCGACGGCATCTTGGGCATGGGCTTCGTCGAGATCTCCGTCATGGGAATCCCC

$\begin{array}{lllllllllllllllllllll}166 & G & V & F & D & G & I & \text { L } & G & M & G & F & \text { V } & \text { E } & \text { I } & \text { S } & \text { V } & \text { M } & \text { G } & \text { I } & \text { P }\end{array}$

601 ACAGTGTTCGACAATATGGTGGCTCAGGGCGTCGTCGATGAACCCATTTTCTCCTTCTTC

$\begin{array}{llllllllllllllllllllll}186 & \mathrm{~T} & \mathrm{~V} & \mathrm{~F} & \mathrm{D} & \mathrm{N} & \mathrm{M} & \mathrm{V} & \mathrm{A} & \mathrm{Q} & \mathrm{G} & \mathrm{V} & \mathrm{V} & \mathrm{D} & \mathrm{E} & \mathrm{P} & \mathrm{I} & \mathrm{F} & \mathrm{S} & \mathrm{F} & \mathrm{F}\end{array}$

661 CTTAACCATGACATGACCGAGACGCTCGGAGGGGAACTGGTGCTGGGCGGGTCAGACCCC

$\begin{array}{lllllllllllllllllllll}206 & \text { L } & \text { N } & \text { H } & \text { D } & \text { M } & \text { T } & \text { E } & \text { T } & \text { L } & G & G & \text { E } & \text { L } & \text { V } & \text { L } & \text { G } & \text { G } & \text { S } & \text { D } & \text { P }\end{array}$

721 AACCACTACGAGGGAGAGTTCCACTACGTCCCAGTCTCCAGGGTGGGCTACTGGCAAATC

$\begin{array}{lllllllllllllllllllll}226 & \mathrm{~N} & \mathrm{H} & \mathrm{Y} & \mathrm{E} & \mathrm{G} & \mathrm{E} & \mathrm{F} & \mathrm{H} & \mathrm{Y} & \mathrm{V} & \mathrm{P} & \mathrm{V} & \mathrm{S} & \mathrm{R} & \mathrm{V} & \mathrm{G} & \mathrm{Y} & \mathrm{W} & \mathrm{Q} & \mathrm{I}\end{array}$

781 ACAGCCGAGGCGATTAAGGTCGGAGGCGTAGACACGACCTTCTGCAGCCCGTGTGAGGCC

$\begin{array}{lllllllllllllllllllll}246 & T & A & E & A & I & K & V & G & G & V & D & T & T & F & C & S & P & C & E & A\end{array}$

841 ATCGTCGACACCGGCACCTCCCTCATCGCTGGACCCAAAGATGAGGTCAAGGAGATCGTA

$\begin{array}{lllllllllllllllllllll}266 & I & V & D & T & G & T & S & L & I & A & G & P & K & D & E & V & K & E & I & V\end{array}$

901 ACCCAGTTAGGAGGGTTCGCCTTCCTTGCTGGAGAGTACCTCATCAACTGCGACAAGGTG

$\begin{array}{lllllllllllllllllllll}286 & \mathrm{~T} & Q & \mathrm{~L} & \mathrm{G} & \mathrm{G} & \mathrm{F} & \mathrm{A} & \mathrm{F} & \mathrm{L} & \mathrm{A} & \mathrm{G} & \mathrm{E} & \mathrm{Y} & \mathrm{L} & \mathrm{I} & \mathrm{N} & \mathrm{C} & \mathrm{D} & \mathrm{K} & \mathrm{V}\end{array}$

961 GAGGAGATGCCGCTCTTCACCTTCACCCTCAACGGCCAGGACTTCGACCTGACAGGACCC

$\begin{array}{lllllllllllllllllllll}306 & \mathrm{E} & \mathrm{E} & \mathrm{M} & \mathrm{P} & \mathrm{L} & \mathrm{F} & \mathrm{T} & \mathrm{F} & \mathrm{T} & \mathrm{L} & \mathrm{N} & \mathrm{G} & \mathrm{Q} & \mathrm{D} & \mathrm{F} & \mathrm{D} & \mathrm{L} & \mathrm{T} & \mathrm{G} & \mathrm{P}\end{array}$

1021 GAGCTGGTCATCGAGAACGTGGACGAGGCCACCGGAGCCAAGACCTGCATTGTGGGCATC

$\begin{array}{lllllllllllllllllllll}326 & \mathrm{E} & \mathrm{L} & \mathrm{V} & \mathrm{I} & \mathrm{E} & \mathrm{N} & \mathrm{V} & \mathrm{D} & \mathrm{E} & \mathrm{A} & \mathrm{T} & \mathrm{G} & \mathrm{A} & \mathrm{K} & \mathrm{T} & \mathrm{C} & \mathrm{I} & \mathrm{V} & \mathrm{G} & \mathrm{I}\end{array}$

1081 CTGGGGCTCGACCTGGGCACCATCGAAGCCTGGATCCTTGGAGACCCATTCATCGCCGAC

$\begin{array}{llllllllllllllllllllll}346 & \mathrm{~L} & \mathrm{G} & \mathrm{L} & \mathrm{D} & \mathrm{L} & \mathrm{G} & \mathrm{T} & \mathrm{I} & \mathrm{E} & \mathrm{A} & \mathrm{W} & \mathrm{I} & \mathrm{L} & \mathrm{G} & \mathrm{D} & \mathrm{P} & \mathrm{F} & \mathrm{I} & \mathrm{A} & \mathrm{D}\end{array}$

1141 TACTACACAGAGTTCGACGTTGGCCAGAAGCGCATTGGTTTTGCCAAATCGATTTAGACG

$\begin{array}{lllllllllllllllllllll}366 & Y & Y & T & E & F & D & V & G & Q & K & R & I & G & F & A & K & S & I & *\end{array}$

1201 ATATTGTCTTCCAAGTTGCCACAACTCTCCTCCCCAACCCCGACCTCCCTTATCTGCCCC

1261 CTACGTCCAAGTGGTTGAGCACCATTCCTTTCCCCCGTCAAATCCCAAATCCTTATCCTG

1321 ACCCCTTCCCAGTGCTTAATGGTCATAATGGCTAAGTGCTGTCTCCTCATAGTTCTCTCT

1381 СTСTCTCTCTTCTCTCTCCCCCACAGCCCTCTATAGCACCCATCCAGCCCCCTCCACTTT

1441 CAAAGGGTGAGGCCGGGATAGGTGGAATAAAAAAAATTGGACTCTGTCGTGATTAGATTT

1501 TCTTTATAGCGAAAAAAAAAAAAAAAAAAAAAAA

Fig. 2 Multiple sequence alignment of the Pc-cathepsin D-like protein from 


\section{Procambarus clarkii with other cathepsin D proteins.}

P. clarkii
P. vannamei
H. americanus
P. carinicauda
P. monodon
H. sapiens
Consensus

P. clarkii

P. vannamei

H. americanus

P. carinicauda

P. monodon

H. sapiens

Consensus

P. clarkii

P. vannamei

H. americanus

P. carinicauda

P. monodon

H. sapiens

Consensus

P. clarkii

P. vannamei

H. americanus

P. carinicauda

P. monodon

H. sapiens

Consensus

P. clarkii

P. vannamei

H. americanus

P. carinicauda

P. monodon

H. sapiens

Consensus

P. clarkii

P. vannamei

H. americanus

P. carinicauda

P. monodon

H. sapiens

Consensus

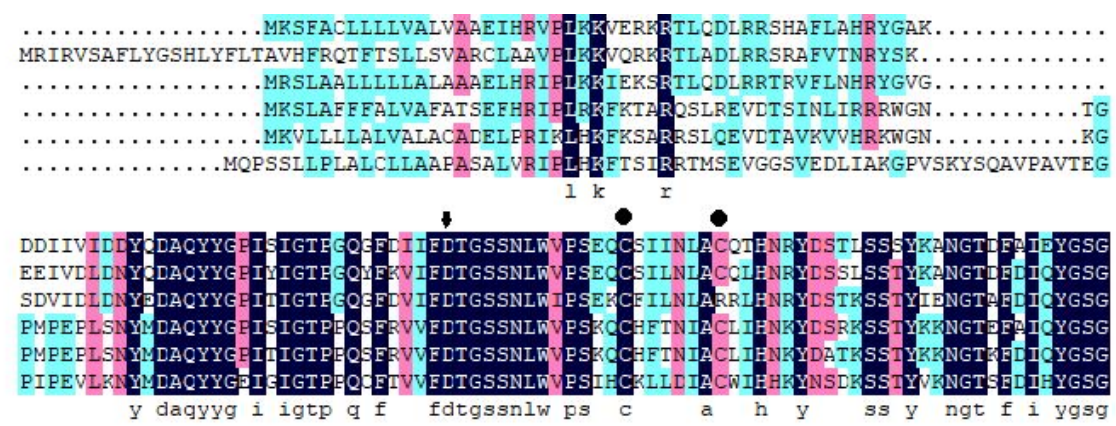

49

66

49

51

65

129

146

129

131

131

145

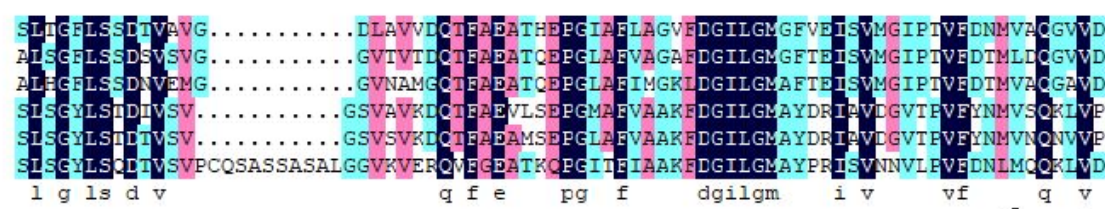

198

215

198

200

225

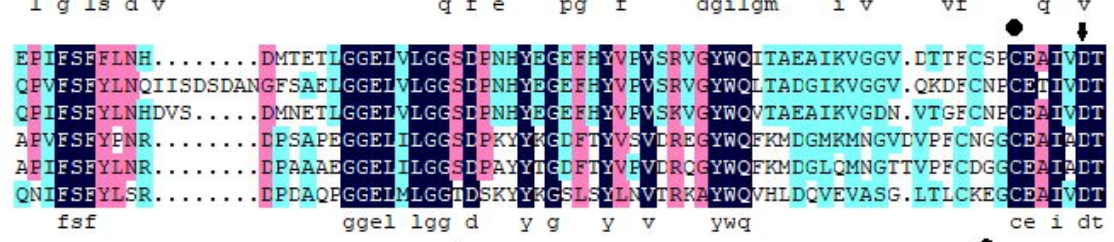

269

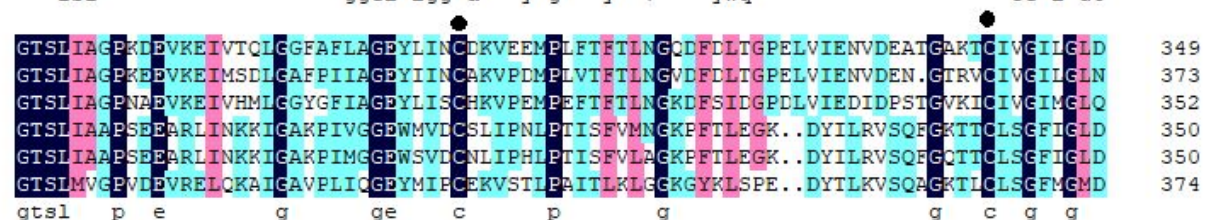

LG. .TIEAWILGLFFIADYYTEFLVGOREIGFRKSI. 383

LG. .TIEAWILGLFE IARYYTBFDVGNKRIGEFIRSV. 407

MG. . ELEZWILGDEF IADWYT PEDVGCRRIGEZIRSI. 386

VPPPMGPIWILGDW IGR YTTEFMGNNRVGFATAA. 386

VPPPMGPIWILGDIFIGR FYTEFDMGNNRVGFAESK. 386

IPPPSGPIWILGD EIGRYYT WDRDNNEVGAEAAR 411

Percentage similarity (aa)

$$
\begin{aligned}
& 73.59 \\
& 74.09 \\
& 50.39 \\
& 49.36 \\
& 47.37
\end{aligned}
$$

Fig. 3. Neighbour-joining phylogenetic for the Procambarus clarkii cathepsin 


\section{D-like amino acid sequence, constructed by MEGA 6 software.}

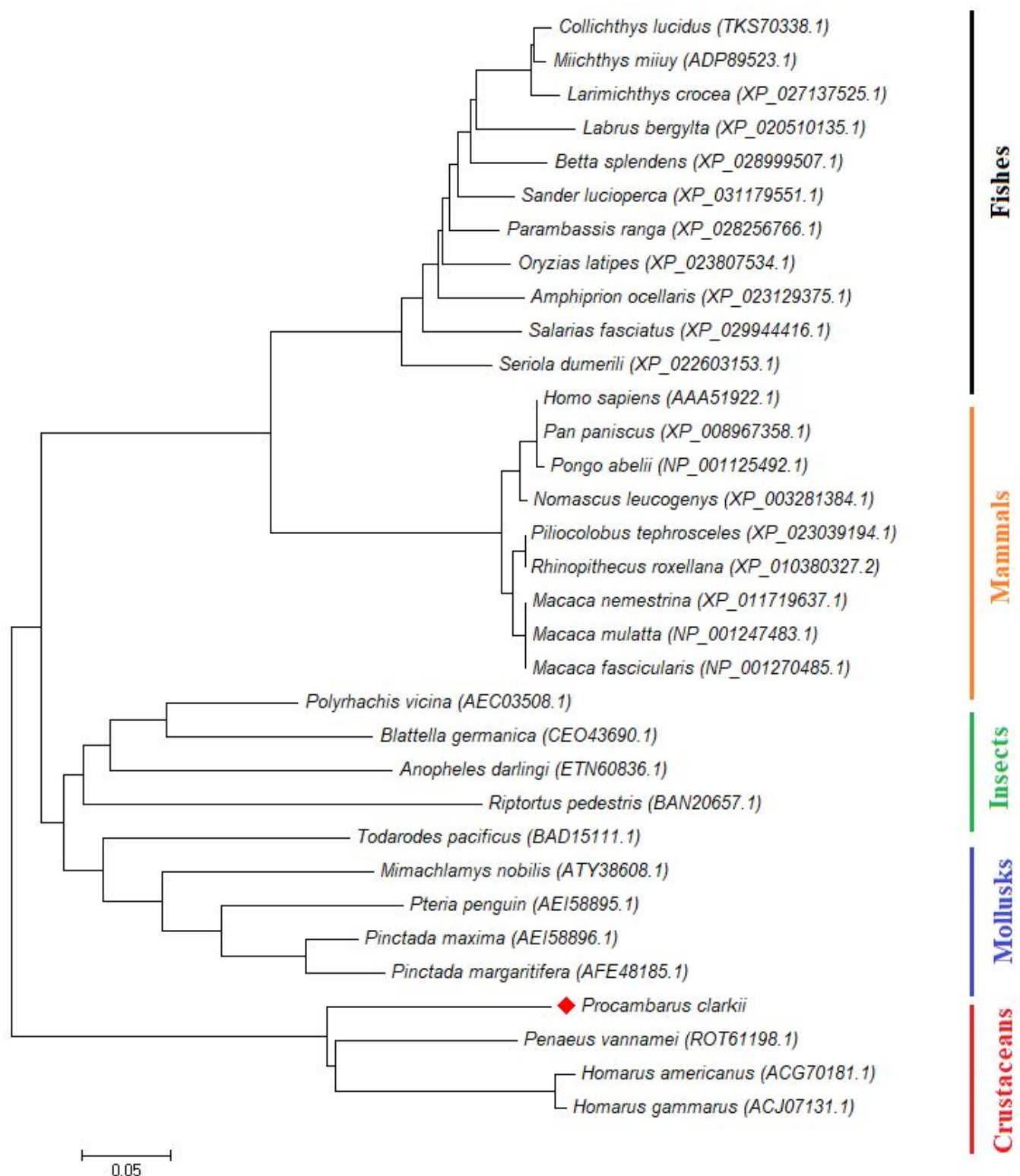

Fig. 4. The expression patterns of Pc-cathepsin D-like in different tissues of 
Procambarus clarkii by qRT-PCR.

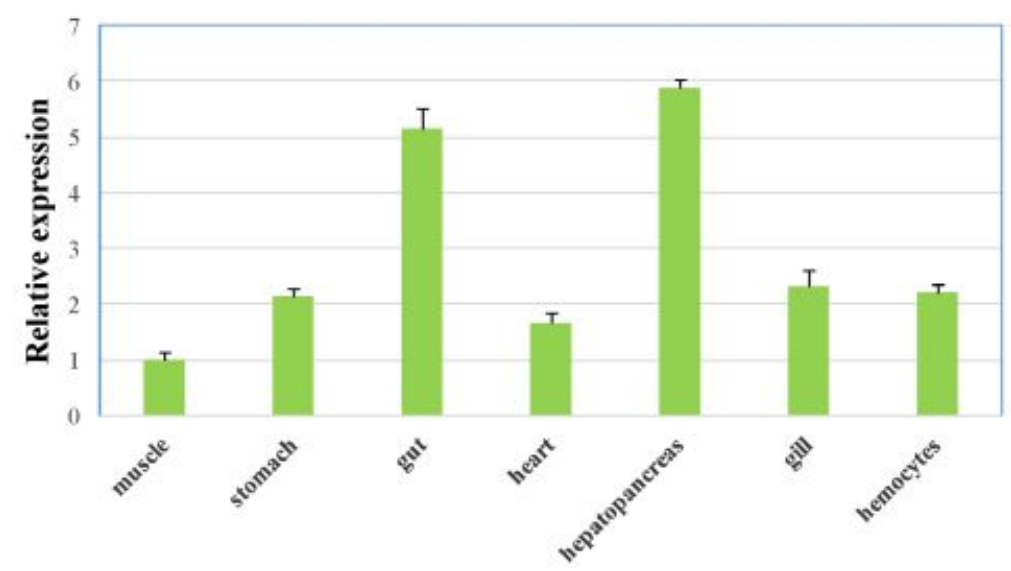

Fig. 5. The Pc-cathepsin D-like expression profiles in the hepatopancreas of Procambarus clarkii following challenge with immune elicitors.

(A)

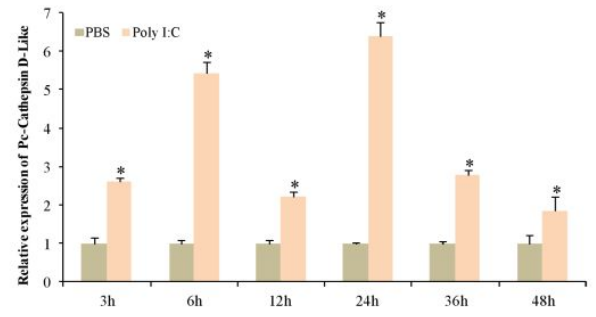

(B)

(C)
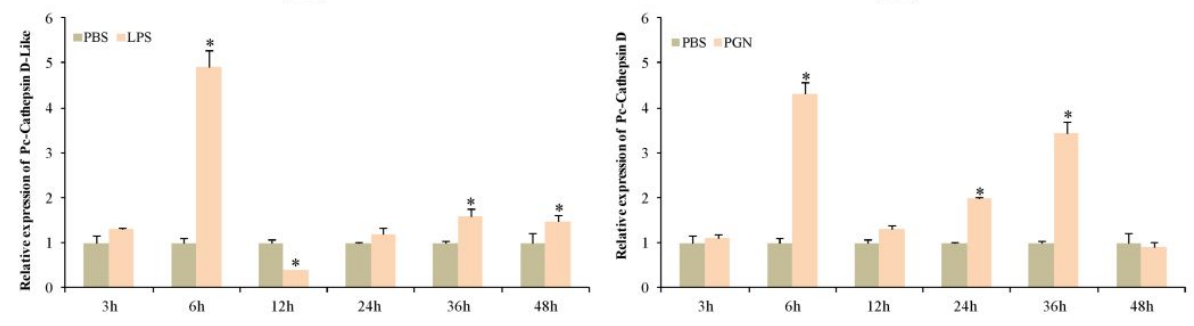

Fig. 6. (A) RNA interference efficiency of Pc-cathepsin D-like in the hepatopancreas of Procambarus clarkii by qRT-PCR. (B) Effects of Pc-cathepsin 
D-like silencing on the expression levels of immune-pathways associated genes.

(A)

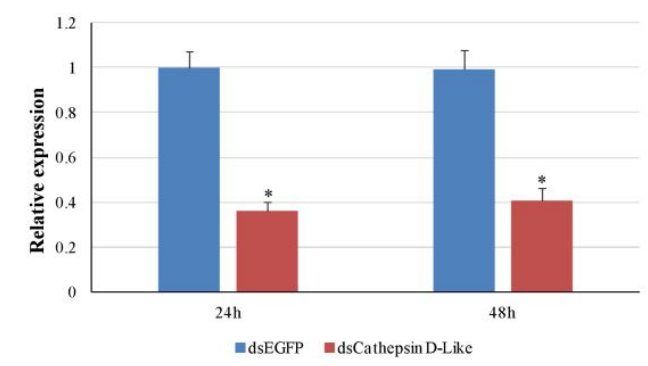

(B)
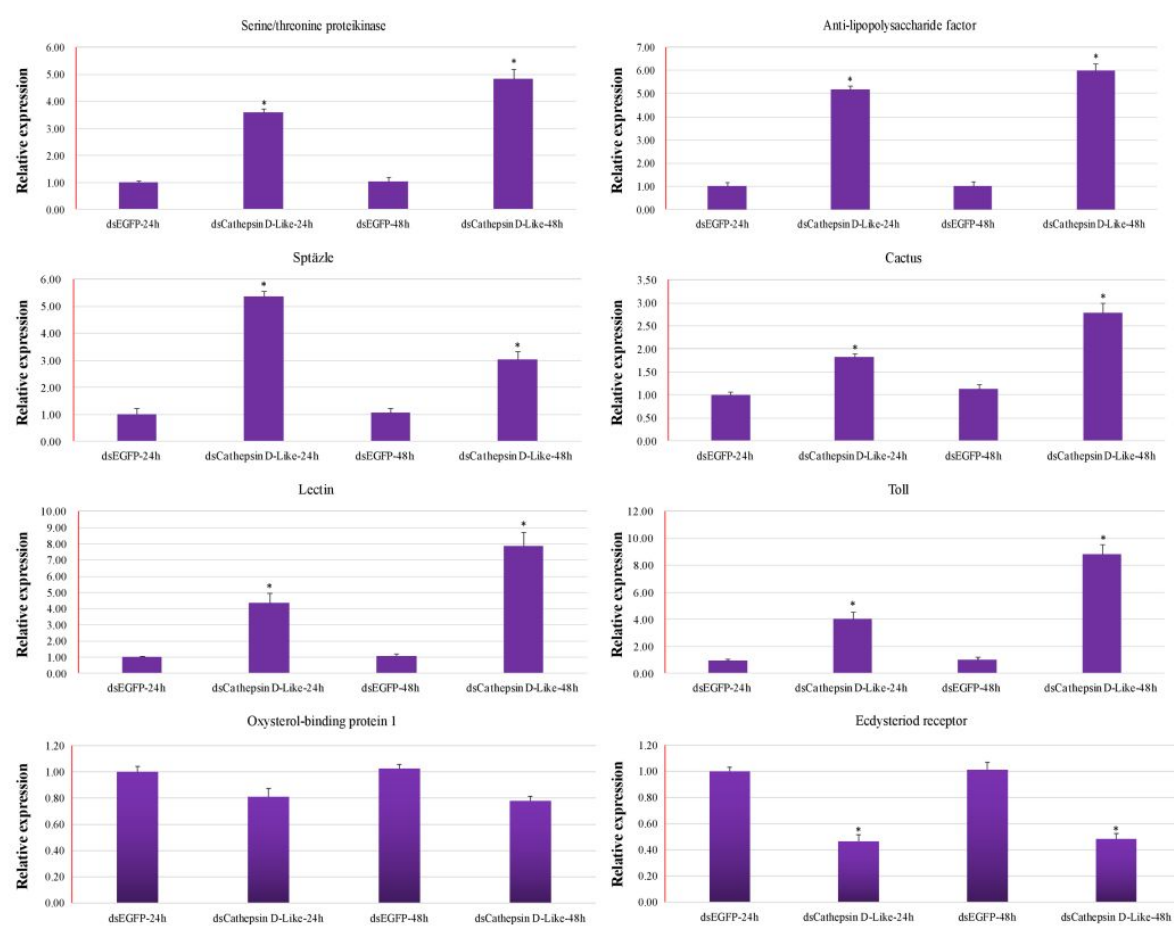
Table 1 Primers used in this study.

\begin{tabular}{|c|c|c|}
\hline Primer No. & Primer sequences $\left(5^{\prime}-3^{\prime}\right)$ & Purpose \\
\hline F1 & ATGAAGTCCTTCGCCTGCCTC & RT-PCR \\
\hline $\mathrm{R} 1$ & ACCAAAACGGTTTAGCTAAATC & RT-PCR \\
\hline $\begin{array}{l}\text { Serine/threonine } \\
\text { protein kinase }-\mathrm{F}\end{array}$ & TGCTATGTGAAGCTCGGCTCT & qPCR \\
\hline $\begin{array}{l}\text { Serine/threonine } \\
\text { protein kinase }-\mathrm{R}\end{array}$ & GCGATCTGATGCTCCTCCTCT & $\mathrm{qPCR}$ \\
\hline ALF-F & TCCTGAATTGCTCCTCGTCA & qPCR \\
\hline ALF-R & GCGGTGGCAACTGTACTTCA & qPCR \\
\hline Sptäzle-F & GTCGGCAGCAACGACATACA & qPCR \\
\hline Sptäzle-R & GGTGTCATGGTTGGCTGTGA & qPCR \\
\hline Cactus-F & CTTGTGAGAGAGCCGTGTGG & qPCR \\
\hline Cactus-R & CAGTACAAGCAGCAGCAGCA & qPCR \\
\hline Lectin-like-F & TGCTCCTGGTGGTAGTGGT & qPCR \\
\hline Lectin-like-R & GTAGAGGTGTTTGGGTGTGG & qPCR \\
\hline Toll3-F & GCTGTTGCTGCTTAGGCTCA & qPCR \\
\hline Toll3-R & TCCTCCACAGCTCTTCATTCC & qPCR \\
\hline Ecdysone receptor-F & TTCCCGAGTCTCAATGCC & qPCR \\
\hline Ecdysone receptor- $\mathrm{R}$ & GAAGAGTGCCGAAACCAG & qPCR \\
\hline $\begin{array}{l}\text { Oxysterol-binding } \\
\text { protein } 1-\mathrm{F}\end{array}$ & TTGCAACGATTAACGGAAGATTTT & qPCR \\
\hline $\begin{array}{l}\text { Oxysterol-binding } \\
\text { protein } 1-\mathrm{R}\end{array}$ & ATGGGCGGATGATGAGACACCTG & qPCR \\
\hline F18S & CTGTGATGCCCTTAGATGTT & qPCR \\
\hline $\mathrm{R} 18 \mathrm{~S}$ & GCGAGGGGTAGAACATCCAA & qPCR \\
\hline dsRNA-EGFP-F & $\frac{\text { GGATCCTAATACGACTCACTATAGGC }}{\text { AGTGCTTCAGCCGCTACCC }}$ & RNAi \\
\hline dsRNA-EGFP-R & $\frac{\text { GGATCCTAATACGACTCACTATAGGA }}{\text { CTCCAGCAGGACCATGTGAT }}$ & RNAi \\
\hline $\begin{array}{l}\text { dsRNA-Cathepsin } \\
\text { D-Like-F }\end{array}$ & $\frac{\text { GGATCCTAATACGACTCACTATAGGG }}{\text { ACACTGGATCGTCCAACCT }}$ & RNAi \\
\hline $\begin{array}{l}\text { dsRNA-Cathepsin } \\
\text { D-Like-R }\end{array}$ & $\frac{\text { GGATCCTAATACGACTCACTATAGGT }}{\text { GCAGAAGGTCGTGTCTACG }}$ & RNAi \\
\hline
\end{tabular}

Note: T7 promoters are in bold and underlined. 